\title{
Employees' Perceptions of Performance Evaluation in the Manufacturing Industry
}

\author{
H E Brand and O J Pretorius
}

Department of Human Resources Management, University of Pretoria

\begin{abstract}
This study determines the management effectiveness of a performance evaluation system in a national manufacturing organisation. This organisation has developed and implemented a new performance evaluation system. After 3 years since implementation, the effectiveness of the system is determined. A questionnaire was used to obtain data from a systematic sample of both employees and supervisors of the organisation. The results show that the organisation should improve certain aspects of its performance evaluation system, like the documentation of information, training of supervisors and communication of strategy and objectives.
\end{abstract}

JEL L 60, M 51

\section{INTRODUCTION}

Organisations today compare well with one another in terms of the utilisation of technology and the resources to obtain this technology. Strategic advantage is therefore not so much found in equipment and technology, but rather in new, innovative strategies, methods and resources (Kaplan \& Norton, 1996). Organisations increasingly seem to focus on their workforce in their search for these strategies, methods and resources. To stay competitive, organisations focus their attention on human resource development in order to develop a workforce which is motivated, skillful and competitive (Williams, 1998).

Performance evaluation plays a decisive role in the development and motivation of employees, and still is management's most effective tool for improving productivity (English, 1991). The management and evaluation of employees' performance is a critical success factor in the future of any organisation. Without a skillful and dedicated work force, no competitive advantage can be obtained (De Waal, 2001).

The importance of performance evaluation can be explained by the following aspects: 


\section{Performance evaluation as a method to execute strategy}

Strategic planning and objectives play an important role in determining the success of an organisation. These objectives must be reached through the actions and behaviour of all employees of the organisation. Performance evaluation is necessary to determine how well or how poor employees reach these objectives, and it also serves as a development aid to employees to help improve their performance (Cascio, 1991). Improved performance thus can be directly linked to an improvement in strategic effectiveness of the organisation.

\section{Performance evaluation and teamwork}

According to Meyer (in Shaw, Scheier \& Baird, 1995), performance evaluation systems should be devised to adapt to the basic operational principles supporting it. The aim of performance evaluation systems should be to provide teams with meaningful information to be utilised in decision making. The focus is thus on the process under control of the team, rather than on the measurement of results.

\section{Performance evaluation and motivation}

Performance evaluation goes hand in hand with the setting of performance standards and objectives. According to Latham and Locke (in Steers \& Porter, 1991), research indicated that the setting of specific, challenging objectives through participation leads to better performance than when general objectives are set. The correct application of performance evaluation and its accompanying objective-setting process, should lead to improved performance in an organisation.

\section{Performance evaluation and other organisational processes}

Performance evaluation should not be seen as a process on its own. It must form an integral part of the greater human resource management system and it has a definite effect on other processes in this system.

\section{Performance evaluation and legal implications}

According to Malos (in Armstrong, 1998), the human resource practitioner should accept that any performance evaluation system will, from time to time, go through a process of legal scrutiny. Most legal disputes around performance evaluation relate to various forms of discrimination inherent in such a system. Malos (in Armstrong, 1998) provides the following suggestions in order to strengthen the legality of a performance evaluation system: 
- $\quad$ Procedures must be standardized and uniform for all employees within a specific job group.

- $\quad$ Procedures must be formally communicated to all stakeholders.

- Procedures must provide the necessary information to employees regarding deviations in performance, as well as opportunities to correct such deviations.

- $\quad$ Evaluations must be accessible to employees, so that it can be revised.

- Performance evaluation must make provision for a formal appeal procedure.

- $\quad$ Performance evaluation must make provision for written instructions and training for evaluators. The performance evaluation process must provide a system to identify and eliminate potential discriminating procedures and results.

The results of legal actions due to the performance evaluation process can cause great harm to the organisation's image, as well as efforts to recruit potential employees. Legal costs alone should prompt the organisation to devise a legally safe and defendable system of performance evaluation, also taking into account all developments in the field of labour legislation.

As was already mentioned, performance evaluation cannot be seen as a secondary process in the organisation, but it must be well managed as a primary process in order to ensure organisational success. In this management process, certain concepts or practices are of critical importance. These concepts are the following:

\section{Coaching}

Coaching all activities relating to the development and improvement of individual performance. It is thus important for each supervisor and manager to be able to execute this activity in order to provide to employees the necessary guidance, and to empower them to improve their performance. Effective coaching skills and methods should be part of the training of performance evaluators (Williams, 2002).

\section{Feedback}

Romanoff (1989) accentuated the importance of training supervisors and managers to effectively provide feedback in the process of performance evaluation. Feedback is used to focus employees' attention on obtaining or reaching certain desired results. Feedback should always be clear, descriptive and constructive. It is also important to provide both positive and negative 
feedback, and to connect negative feedback with coaching activities in order to improve performance.

\section{Objectives and strategic management}

Williams (1998) indicated that performance evaluation should be closely related to the objectives of the organisation. Organisations should also distinguish between training objectives, needs, business objectives and challenges. According to Kaplan and Norton (1996), the organisation should strive to divide its vision into smaller tasks which should be executed in order to realise this vision. The vision should be rolled down to the lowest levels in the organisation in order to attain alignment among all activities in the organisation. This process influences the way employees are evaluated, as well as how objectives are implemented and reached.

\section{Remuneration}

According to English (1991), many organisations keep performance evaluation systems and remuneration systems apart from one another, due to the fact that they do not have the ability to successfully connect these two activities. English (1991) also points to the fact that the manner in which performance is linked to remuneration has an important effect on individual work motivation. Weiss (1997) indicated that recent developments in the National Qualifications Framework in South Africa are forcing organisations to investigate the manner in which employees are remunerated for performance and participation. The relationship between performance and remuneration should be clear and decisions should be made about how performance evaluation can influence the remuneration system and vice versa. Performance evaluation and the criteria used for such evaluation can have a significant impact on the remuneration system of an organisation (De Waal, 2001).

\section{Training}

Performance evaluation has a logical impact on training and staff development (Bacal, 1999). Training and development can only be optimally executed in situations where it can de directly related to development opportunities and/or behaviour deficiencies. Performance evaluation serves as an effective way to determine employees' abilities to perform certain duties successfully and to identify training needs. The performance evaluation interview can, for example, be used as an opportunity to compile an individual development plan for each employee. 


\section{Labour relations}

Few organisations realise the impact of performance evaluation on labour relations. According to Romanoff (1989), the employer obtains employee support and devotion by involving employees in the development process of a performance evaluation system. Performance evaluation systems also contain criteria which could relate closely to labour relations. Organisations often do not really comprehend the impact of poor labour relations on employee performance. The quality of labour relations could have either a positive or negative influence on performance and hence on performance evaluation. Cooperation between management and employees during the development of a performance evaluation system provides management with the opportunity to explain and clarify expectations and values. This leads to a better understanding of all organisational activities and should also improve labour relations.

\section{Human resource planning}

This concept or practice relates closely to performance evaluation, as the latter is also used for employee development. By co-ordinating such development with human resource planning, opportunities for promotion of employees can be created. The organisation also creates the opportunity to determine future human resource needs and how these needs will be met (Bacal, 1999).

It is clear that performance evaluation has a definite influence on individual and team motivation, as well as all organisational processes. It is a critical important instrument in employee motivation and serves as a key instrument in the management of human resources in the organisation. The management of every organisation, in co-operation with all employees, should be responsible for the creation of a system wherein activities such as the planning, communication, feedback and control of performance evaluation can take place. The management of performance evaluation should thus be an integral part of the strategic management system of the organisation, indicating that a performance evaluation system should be continually evaluated and maintained (Wade, 2000).

\section{RESEARCH METHOD}

\section{Respondents}

The respondents in this study consisted of all employees $(\mathrm{N}=1205)$ in the organisation evaluated by the specific performance evaluation system, as well as all supervisors involved in the performance evaluation process $(\mathrm{N}=380)$. A 
randomized sample was drawn from these respondents, resulting in a total of 720 respondents, consisting of 530 employees and 190 supervisors. Department and number of individual performance evaluations done, were utilised as biographical variables.

Departments or sections primarily involved in the production side of the organisation formed 35 per cent of the research group, the rest consisting of departments more on the administrative side. The majority of the research group is male ( 91 per cent). 35 per cent of the research group was evaluated four times (or more), 28 per cent three times, 27 per cent two times and 10 per cent once.

\section{Procedure}

A total of 720 questionnaires were sent out (530 to employees and 190 to supervisors). In an accompanying letter, all participants were assured that the information would be handled confidentially and that the research is done with the approval of management and union representatives. A total of 88 completed questionnaires (46 per cent) were received from supervisors and 214 (40 per cent) from employees.

\section{Measuring instrument}

\section{Questionnaire: Profile of your ideal Performance Management Programme.}

This questionnaire consists of four sections, each focussing on an important area of performance evaluation management. The first section focuses on the implementation of strategy in the organisation, referring to the utilisation of the setting of objectives in the organisation (questions 1-4). The second section focuses on the continuity of, participation in and judicial basis of the performance evaluation system (questions 5-10). The third section focuses on management's involvement in and commitment to the implementation and appliance of the system (questions 11-19). The fourth section focuses on training provided in the field of performance evaluation in the organisation (questions 20-29). Question statements are answered according to a 7-point scale, ranging from 1 (do not agree at all) to 7 (agree to a great deal).

The reliability of the questionnaire was determined by using the SpearmanBrown method, obtaining a coefficient of 0.92. A Cronbach's Alpha of 0.93 was also obtained. 


\section{Statistical analysis}

This analysis was done by means of the SPSS for Windows computer programme. The data derived from the questionnaires were analysed by means of descriptive and inferential statistics of the mentioned computer programme. Although various statistical methods were used to evaluate the data, only the results of the descriptive statistics and one way analysis of variance will be reported in this article.

\section{RESULTS OF THE STUDY}

The descriptive statistics of the questionnaire are depicted in Table 1. The results of the one-way analysis of variance are depicted in Tables 2 and 3.

Table 1 Descriptive statistics of the questionnaire: Profile of your actual/ideal performance management programme

\begin{tabular}{|c|c|c|c|c|c|c|c|}
\hline \multicolumn{2}{|c|}{ Sections \& Items } & \multirow{2}{*}{$\begin{array}{l}\text { Mean } \\
4.695\end{array}$} & \multirow{2}{*}{$\begin{array}{c}\text { SD } \\
2.332\end{array}$} & \multirow{2}{*}{$\begin{array}{c}\begin{array}{c}\text { Skew- } \\
\text { ness }\end{array} \\
-0.242 \\
\end{array}$} & \multirow{2}{*}{$\begin{array}{c}\begin{array}{c}\text { SE of the } \\
\text { mean }\end{array} \\
0.088 \\
\end{array}$} & \multirow{2}{*}{$\begin{array}{c}\text { Kurtosis } \\
-0.534 \\
\end{array}$} & \multirow{2}{*}{$\begin{array}{c}\frac{\sigma_{\text {Va- }}}{\text { riance }} \\
1.527\end{array}$} \\
\hline \multirow{4}{*}{$\begin{array}{l}\text { Implemen } \\
\text {-tation of } \\
\text { strategy }\end{array}$} & 1 & & & & & & \\
\hline & 2 & 4.801 & 2.286 & -0.240 & 0.087 & -0.817 & 1.512 \\
\hline & 3 & 5.606 & 1.841 & -0.904 & 0.078 & 0.387 & 1.357 \\
\hline & 4 & 4.851 & 2.473 & -0.386 & 0.090 & -0.709 & 1.572 \\
\hline \multirow{6}{*}{$\begin{array}{l}\text { The } \\
\text { perfor- } \\
\text { mance } \\
\text { evaluation } \\
\text { system }\end{array}$} & 5 & 4.596 & 2.188 & -0.235 & 0.085 & -0.568 & 1.479 \\
\hline & 6 & 4.447 & 2.613 & -0.175 & 0.093 & -0.762 & 1.617 \\
\hline & 7 & 4.414 & 2.516 & -0.138 & 0.091 & -0.778 & 1.586 \\
\hline & 8 & 4.404 & 2.580 & -0.101 & 0.092 & -0.791 & 1.606 \\
\hline & 9 & 4.821 & 2.559 & -0.318 & 0.092 & -0.866 & 1.600 \\
\hline & 10 & 4.755 & 2.431 & -0.317 & 0.090 & -0.656 & 1.559 \\
\hline \multirow{9}{*}{$\begin{array}{l}\text { Manage- } \\
\text { ment's } \\
\text { involve- } \\
\text { ment and } \\
\text { commit- } \\
\text { ment }\end{array}$} & 11 & 4.861 & 2.446 & -0.366 & 0.090 & -0.723 & 1.564 \\
\hline & 12 & 4.841 & 2.234 & -0.459 & 0.086 & -0.309 & 1.495 \\
\hline & 13 & 4.841 & 2.639 & -0.406 & 0.093 & -0.652 & 1.625 \\
\hline & 14 & 4.417 & 2.948 & -0.154 & 0.099 & -0.898 & 1.717 \\
\hline & 15 & 4.606 & 2.173 & -0.200 & 0.085 & -0.482 & 1.474 \\
\hline & 16 & 5.298 & 1.931 & -0.650 & 0.080 & -0.080 & 1.390 \\
\hline & 17 & 4.123 & 3.317 & -0.050 & 0.105 & -1.087 & 1.821 \\
\hline & 18 & 4.394 & 2.685 & -0.171 & 0.094 & -0.861 & 1.639 \\
\hline & 19 & 4.583 & 3.214 & -0.246 & 0.103 & -1.077 & 1.793 \\
\hline \multirow{3}{*}{$\begin{array}{l}\text { Training } \\
\text { in per- } \\
\text { form. eval. }\end{array}$} & 20 & 4.732 & 2.509 & -0.208 & 0.091 & -0.799 & 1.584 \\
\hline & 21 & 4.785 & 2.535 & -0.309 & 0.092 & -0.750 & 1.592 \\
\hline & 22 & 4.901 & 2.249 & -0.496 & 0.086 & -0.435 & 1.500 \\
\hline
\end{tabular}


Table 1 continued

\begin{tabular}{|l|c|c|c|c|c|c|c|}
\hline \multicolumn{2}{|c|}{ Sections \& Items } & Mean & SD & $\begin{array}{c}\text { Skew- } \\
\text { ness }\end{array}$ & $\begin{array}{c}\text { SE of the } \\
\text { mean }\end{array}$ & Kurtosis & $\begin{array}{c}\text { Va- } \\
\text { riance }\end{array}$ \\
\hline \multirow{4}{*}{$\begin{array}{l}\text { Training } \\
\text { in } \\
\text { perform. } \\
\text { evaluation }\end{array}$} & 23 & 4.556 & 2.540 & -0.230 & 0.092 & -0.614 & 1.594 \\
\cline { 2 - 8 } & 24 & 4.884 & 2.222 & -0.394 & 0.086 & -0.440 & 1.491 \\
\cline { 2 - 8 } & 25 & 4.705 & 2.474 & -0.360 & 0.091 & -0.595 & 1.573 \\
\cline { 2 - 8 } & 26 & 4.444 & 2.680 & -0.119 & 0.094 & -0.788 & 1.637 \\
\cline { 2 - 8 } & 28 & 4.623 & 2.515 & -0.294 & 0.091 & -0.618 & 1.586 \\
\cline { 2 - 8 } & 29 & 4.411 & 2.416 & -0.172 & 0.089 & -0.708 & 1.554 \\
\hline \hline
\end{tabular}

As is evident from Table 1, the mean scores vary between 4 to 5 , indicating that the respondents agree to an extent with the statements made in the questionnaire. It is also clear that the distribution is not normal, as the kurtosis is platicurtic. The values are all smaller than 0,263 . The skewness coefficient is generally smaller than zero (0). However, the values of the Standard Error of Mean is quite large, indicating that the results cannot be generalised to the population.

As regards inferential statistics, an One-Way Analysis of Variance was done to determine significant differences, if any, between the organisation departments on the 29 questions of the questionnaire. The results are presented in Table 2.

Table 2 One-way Analysis of Variance results for the independent variable: Department

\begin{tabular}{|c|c|c|}
\hline Variable & F-relation & Significance \\
\hline Question 1 & 1.2313 & 0.2943 \\
\hline Question 2 & 4.6800 & $0.0004^{*}$ \\
\hline Question 3 & 1.4008 & 0.2238 \\
\hline Question 4 & 2.1211 & 0.0629 \\
\hline Question 5 & 1.6248 & 0.1532 \\
\hline Question 6 & 0.9537 & 0.4466 \\
\hline Question 7 & 2.0293 & 0.0745 \\
\hline Question 8 & 3.8752 & $0.0020^{*}$ \\
\hline Question 9 & 1.7158 & 0.1308 \\
\hline Question 10 & 0.7961 & 0.5532 \\
\hline Question 11 & 1.4793 & 0.1964 \\
\hline Question 12 & 0.9533 & 0.4469 \\
\hline Question 13 & 2.1944 & 0.0549 \\
\hline Question 14 & 2.6449 & $0.0234^{*}$ \\
\hline Question 15 & 3.1230 & $0.0092^{*}$ \\
\hline
\end{tabular}


Table 2 continued

\begin{tabular}{|c|c|c|}
\hline Variable & F-relation & Significance \\
\hline Question 16 & 2.4315 & $0.0351^{*}$ \\
\hline Question 17 & 1.5572 & 0.1721 \\
\hline Question 18 & 1.9227 & 0.0904 \\
\hline Question 19 & 5.2119 & $0.001^{*}$ \\
\hline Question 20 & 1.4227 & 0.2159 \\
\hline Question 21 & 1.9605 & 0.0844 \\
\hline Question 22 & 1.7552 & 0.1220 \\
\hline Question 23 & 1.5936 & 0.1617 \\
\hline Question 24 & 1.2390 & 0.2908 \\
\hline Question 25 & 2.0610 & 0.0703 \\
\hline Question 26 & 1.5211 & 0.1830 \\
\hline Question 27 & 1.6777 & 0.1398 \\
\hline Question 28 & 2.1371 & 0.0611 \\
\hline Question 29 & 3.4095 & $0.0052^{*}$ \\
\hline
\end{tabular}

$\mathrm{P} \leq 0.05$

It is clear from Table 2 that the independent variable "Department" has a significant effect on Questions 2, 8, 14, 15, 16, 19 and 29.

Question two (2) refers to the organisation's encouragement of managers to regularly communicate senior management's vision and objectives throughout the organisation.

It is clear that different departments also differ on the performance management system's inclusion of extensive orientation and training for all (question 8). The various departments also differ with regards to the employees' involvement in the successful implementation of the performance appraisal system (question 14). Question 15 relates to the link between strategic business planning and the performance management system. This system and its integration with other key systems, for example quality improvement, productivity improvement and succession planning, was also perceived significantly different by the various departments. Question 19, another factor of significant differences, refers to the appraisal results and its utilisation in determining training needs. The training provided in support of performance evaluation systems, which includes ways of measuring the effective utilisation of skills in the job context (question 29), was another bone of contention between the various departments.

Post Hoc comparisons were done by means of the Scheffe Test to determine which groups differ significantly from one another. 
- As regards communication of organization objectives and vision, departmental group 6 (human resources \& services; financial) seems to differ significantly from group 4 (technology and logistics) and group 5 (engineering works; support services).

- As regards orientation and training, departmental group 6 (human resources \& Services; financial) seems to differ significantly from group 5 (engineering works; support services).

- As regards employees' dedication to the implementation of performance evaluation, departmental group 6 (human resources \& services; financial) again seems to differ significantly from group 5 (engineering works; support services).

- As regards the relation between strategic planning and performance evaluation, departmental group 5 (engineering works; support services) seems to differ significantly from group 6 (human resources \& services; financial).

- As regards the extent to which evaluation results are utilized in the process of training planning, departmental group 5 (engineering works; support services) seems to differ significantly from group 1 (raw materials $\&$ steelworks), group 2 (roller works), group 3 (cold products), group 4 (plate technology; logistics) and group 6 (human resources \& services; financial).

- $\quad$ As regards the extent to which the application of skills in the workplace is evaluated, departmental groups 5 (engineering works; support services) and 6 (human resources \& services; financial) seem to differ significantly.

The results of the One-Way Analysis of Variance regarding the number of times respondents were evaluated by the performance evaluation system are depicted in Table 3.

Table 3 One-way Analysis of Variance results for the independent variable: number of times evaluated

\begin{tabular}{|c|c|c|}
\hline Variable & F- relation & Significance \\
\hline Question 1 & 0.0204 & 0.9798 \\
\hline Question 2 & 0.2332 & 0.7922 \\
\hline Question 3 & 0.1110 & 0.8950 \\
\hline Question 4 & 0.2946 & 0.7450 \\
\hline Question 5 & 0.1991 & 0.8196 \\
\hline Question 6 & 0.1983 & 0.8202 \\
\hline Question 7 & 0.7851 & 0.4570 \\
\hline Question 8 & 0.3753 & 0.6874 \\
\hline Question 9 & 0.7058 & 0.4945 \\
\hline
\end{tabular}




\begin{tabular}{|c|c|c|}
\hline Variable & F- relation & Significance \\
\hline Question 10 & 0.2737 & 0.7608 \\
\hline Question 11 & 1.0195 & 0.3620 \\
\hline Question 12 & 1.2652 & 0.2837 \\
\hline Question 13 & 0.0087 & 0.9914 \\
\hline Question 14 & 1.3261 & 0.2671 \\
\hline Question 15 & 1.5843 & 0.2068 \\
\hline Question 16 & 1.2535 & 0.2870 \\
\hline Question 17 & 1.5727 & 0.2092 \\
\hline Question 18 & 1.1141 & 0.3296 \\
\hline Question 19 & 0.5260 & 0.5915 \\
\hline Question 20 & 1.4388 & 0.2389 \\
\hline Question 21 & 1.1195 & 0.3278 \\
\hline Question 22 & 2.4342 & 0.0894 \\
\hline Question 23 & 0.5831 & 0.5588 \\
\hline Question 24 & 0.4788 & 0.6200 \\
\hline Question 25 & 0.3291 & 0.7198 \\
\hline Question 26 & 0.0532 & 0.9482 \\
\hline Question 27 & 0.2367 & 0.7894 \\
\hline Question 28 & 0.6709 & 0.5120 \\
\hline Question 29 & 1.2885 & 0.2772 \\
\hline
\end{tabular}

$\mathrm{P} \leq 0.05$

It is evident from Table 3 that the independent variable "Number of Times Evaluated" does not have any significant effect on any one of the dimensions of the questionnaire.

\section{DISCUSSION}

This study and the literature study done on performance evaluation, indicate that the effectiveness of performance evaluation can be adequately evaluated according to four aspects, namely the relation between performance evaluation and organisation strategy, the participation of all stakeholders in the development process of an evaluation system, the participation and commitment of all stakeholders in the process of implementation and execution of the process and the training involved in the application of the system (Armstrong, 1998; De Waal, 2001; Wade, 2000; Williams, 2002). This study focussed on a specific organisation and its employees' and supervisors' perceptions relating to the stated four aspects. The following conclusions can be drawn from the study : 
The questionnaire used (Profile of your actual/ideal performance management system) seems to be reliable for the evaluation of the effectiveness of a performance evaluation system. The standard error, however, is significantly large, indicating that the results cannot be generalised to the population from which the sample was drawn.

There seems to be no significant differences between employees' and supervisors' perceptions regarding the effectiveness of the performance evaluation system.

There seems to be a strong relation between employees' perceptions regarding the following aspects:

- $\quad$ The extent to which management communicates with employees regarding the organisation's vision and objectives, and employees' perception of their involvement in organisation decision making.

- The extent to which training in the organisation empower employees to effectively define jobs and performance standards.

- The extent to which training assist supervisors to provide the right feedback on performance areas that need improvement and perceptions of management's commitment to and involvement in the successful implementation of the performance evaluation system.

- The extent to which training enable supervisors to address performance problems and how well supervisors utilise the system of performance evaluation as an aid to development in the organisation.

- The extent to which supervisors, during training, are given the opportunity to exercise their skills and their perceived ability to address performance problems.

- The extent to which supervisors, during training, are given the opportunity to exercise their skills and employees' perceptions of the extent to which supervisors learn to determine how well they (employees) apply their skills in the workplace.

From the study it also seems as if the department or section to which a respondent belong, could have an influence on the respondent's perception of the training, the extent to which strategy is related to performance evaluation, participation in the system, and involvement of all stakeholders in the system. Departments or sections appear to differ significantly on these aspects. These findings to al large extent also correspond with findings by Latham and Wexley (1994), Matheson et al. (1995) and Williams (1998).

The number of times respondents were evaluated with the performance evaluation system do not appear to have a significant influence on their perceptions regarding involvement, participation, training and strategy. 
The One-way analysis of variance done with regard to the various departments/sections of the organisation, seems to indicate that respondents in the different departments do differ significantly in their responses to certain questions. The post hoc comparisons done to determine which groups differ significantly from one another, seem to indicate significant differences on certain dimensions of the questionnaire.

In conclusion, the results of the study seem to indicate that an improvement in training regarding performance evaluation in the organisation is necessary, due to the following reasons :

- Training has an influence on the assessor's ability to determine performance standards.

- Training improves the measure of objectivity in the performance evaluation system.

Employees' perceptions regarding management's dedication are influenced by the latter party's ability to evaluate correctly and to provide accurate feedback. The better assessors are equipped to identify performance problems, the better the system can be utilised as a development aid. Training does not include enough opportunities for assessors to practice their skills before returning to the workplace.

\section{REFERENCES}

1 ANDERSON, G.C. (1993) Managing Performance Appraisal Systems, Blackwell: Oxford.

2 ARMSTRONG, M. (1998) Performance Management: The New Realities, Institute of Personnel and Development: London.

3 BACAL, R. (1999) Performance management. New York: McGraw-Hill.

4 CASCIO, W.F. (1991) Applied Psychology in Personnel Management (4 $^{\text {th }}$ ed.) Englewood Cliffs, Prentice-Hall: New Jersey.

5 DE WAAL, A. (2001) Power of Performance Management: How Leading Companies Create Sustained Value, Wiley: New York.

6 ENGLISH, G. (1991) "Tuning up for performance management", Training and Development Journal, 10(9): 56-60.

$7 \quad$ KAPLAN, R.S. \& NORTON, D.P. (1996) "Using the balanced scorecard as a strategic management system", Harvard Business Review, 9(3): 7585.

8 LATHAM, G.P. \& WEXLEY, K.N. (1994) Increasing Productivity through Performance Appraisal, Addison-Wesley: Reading, Mass.

9 MATHESON, W., VAN DYK, C. \& MILLAR, K. (1995) Performance Evaluation in the Human Services, Haworth: New York. 
10 ROMANOFF, K.E. (1989) "The ten commandments of performance management", Personnel, 61 (3): 24-8.

11 SHAW, D.G., SCHEIER, B. \& BAIRD, C. (1995) Performance Measurement, Management and Appraisal Sourcebook, Human Resource Development Press: Amherst.

12 STEERS, R.M. \& PORTER, L.W. (1991) Motivation and Work Behaviour ( $5^{\text {th }}$ ed.) McGraw-Hill, Inc: Singapore.

13 WADE, D. (2000) Corporate Performance Management: How to Build a Better Organization through Measurement-driven Strategic Alignment, Butterworth-Heinemann: Boston.

14 WEISS, T.B. (1997) Reengineering Performance Management: Breakthroughs in Achieving Strategy through People, Lucie Press: Boca Raton, Fla.

15 WILLIAMS, R.S. (2002) Managing Employee Performance: Design and Implementation in Organisations, Thomson Learning: London.

16 WILliAMS, R.S. (1998) Performance Management: Perspectives on Employee Performance, International Thomson Business Press: Boston. 